\title{
EFEK MOTIVASI DAN REMUNERASI DI DALAM PENGARUH WORK PASSION TERHADAP KINERJA
}

\author{
Silvester Sedu Kemie* \\ Program Studi Mesin Industri, Politeknik Industri ATMI, Indonesia
}

\begin{abstract}
Humans are a key factor in the process and achievement of organizational success. Therefore, organizations must develop and enable their workforce to have optimal performance. This study aims to examine the effect of work passion on employee performance at the Politeknik Industri ATMI with mediation from motivation and remuneration. Data were collected using non-probality sampling method with saturation sampling technique for 69 employees. Testing uses data that has been tested for validity and reliability using SPSS V.23 software and macros indirect Hayes 2013. The results showed that work passion and remuneration don't significantly influence performance. Work passion can have a significant effect when mediated by motivation. A significant direct effect on performance is given by motivation. Motivation is a dominant force in improving performance.
\end{abstract}

Keyword: Motivation; Performance; Remuneration; Work Passion

\begin{abstract}
Abstrak
Manusia adalah faktor kunci di dalam proses dan pencapaian sukses organisasi. Oleh karena itu, organisasi harus mengembangkan dan memampukan tenaga kerjanya untuk memiliki kinerja yang optimal. Penelitian ini bertujuan untuk menguji pengaruh gairah kerja terhadap kinerja pegawai di Politeknik Industri ATMI dengan mediasi dari motivasi dan remunerasi. Data dikumpulkan dengan menggunakan metode pengambilan sampel non-probality sampling dengan teknik sampel jenuh terhadap 69 pegawai. Pengujian menggunakan data yang telah teruji validitas dan realibilitas dengan menggunakan software SPSS V.23 dan macros indirect Hayes 2013. Hasil penelitian menunjukkan bahwa gairah kerja dan remunerasi tidak berpengaruh signifikan terhadap kinerja. Gairah kerja baru dapat memberikan pengaruh yang signifikan bila dimediasi oleh motivasi. Pengaruh langsung yang signifikan terhadap kinerja diberikan oleh motivasi. Motivasi merupakan kekuatan yang dominan dalam meningkatkan kinerja organisasi.
\end{abstract}

Kata Kunci: Gairah Kerja; Kinerja; Motivasi; Remunerasi

Article History: Received: (19-08-2020); Revised: (05-10-2020); and Published: (31-10-2020) Copyright (C) 2020 Silvester Sedu Kemie

How to cite this article: Kemie, S. S. (2020). Efek Motivasi Dan Remunerasi Di Dalam Pengaruh Work Passion Terhadap Kinerja. Managament Insight: Jurnal IImiah Manajemen.15 (2); 190207

Retrevied from: https://ejournal.unib.ac.id/index.php/Insight 


\section{PENDAHULUAN}

Menurut (Tanner, 2004), salah satu tujuan organisasi adalah memaksimalkan nilai-nilai organisasi dengan sumber daya yang dimilikinya untuk mencapai kesuksesan. Sumber daya yang dimaksud dapat berupa sumber daya keuangan, fisik, manusia, pengetahuan, dan organisasi umum. Sebuah organisasi dikatakan sukses bila dalam jangka panjang organisasi secara efektif mampu menyediakan, mengembangkan, memampukan, dan mengatur sumber daya tersebut sehingga memberikan keuntungan maksimal. Tidak dapat dikesampingkan juga bahwa faktor kunci dalam proses dan kesuksesan organisasi adalah manusia (Holbeche, 2005). Oleh karena itu, pengukuran kinerja organisasi saat ini tidak lagi sekedar melalui pencapaian finansial semata melainkan juga human capital yang dimilikinya. Karena manusia menjadi faktor kunci, maka kinerja pegawai yang tinggi menjadi kontribusi paling besar bagi keberhasilan organisasi (Munandar., 2001).

Kinerja yang tinggi juga menjadi perspektif penting bagi Politeknik Industri ATMI (Polin ATMI). Dengan dream menjadi politeknik "kelas dunia" membuat manajemen Polin ATMI harus memikirkan peningkatan kinerja pegawainya. Polin ATMI sebagai lembaga pendidikan yang memiliki misi mendidik kaum muda menjadi tenaga profesional yang memiliki kemampuan teknik dan tanggung jawab moral, harus didukung oleh sumber daya manusia yang berkualitas, berkinerja baik, dan memiliki motivasi kerja yang tinggi agar program-program kerja institusi dapat terlaksana dengan baik. Para pegawai Polin ATMI harus memiliki work passion. Penelitian yang dilakukan (Vallerand, 2008) menegaskan bahwa seseorang dengan tingkat work passion yang tinggi akan lebih mencintai pekerjaannya karena mau memberikan talenta, waktu, dan energinya yang berdampak pada peningkatan self esteem sehingga mereka selalu ingin meningkatkan kinerjanya. Namun, menurut (Ho et al., 2011) di dalam penelitiannya, pengaruh work passion terhadap kinerja masih dibutuhkan pengujian lebih lanjut karena masih sedikit penelitian yang mendalami konsep ini. Hal ini memberikan ketertarikan bagi penulis untuk menguji lebih jauh tingkat pengaruh work passion pegawai Polin ATMI terhadap kinerja.

Untuk meningkatkan kinerja apakah seseorang cukup dengan memiliki work passion saja? Apakah masih diperlukan suatu motivasi tertentu? Mengikuti pernyataan McClelland bahwa motivasi utama seseorang dalam bekerja dapat dibagi atas 3 jenis, yaitu: motivasi untuk berprestasi, motivasi untuk berkuasa, dan motivasi untuk berafiliasi (Robbins, 2006). Menurutnya, pemberian motivasi dapat memberikan efek positif untuk meningkatkan kinerja karyawan dalam pencapaian target kerja organisasi. Motivasi juga menjadi salah satu penentu penting untuk pencapaian prestasi kinerja individu dalam organisasi. Dampak dari motivasi adalah terciptanya gairah karyawan sehingga produktivitas karyawan akan meningkat. Gairah kerja sebagai salah satu bentuk motivasi dapat dilihat misalnya dari tingkat kehadiran pegawai dan tanggung jawab terhadap waktu kerja yang telah ditentukan. Jika seseorang memiliki motivasi kerja yang tinggi maka dia akan berkinerja baik pula, sehingga tujuan yang ingin dicapai 
organisasi dapat terwujud. Dalam penelitian ini, penulis akan menguji juga apakah upaya peningkatan kinerja pegawai di Polin ATMI cenderung dipengaruhi oleh motivasi tertentu atau work passion semata.

Ketika seseorang mencapai suatu kinerja yang baik tentu saja yang diharapkan adalah peningkatan remunerasi. Menurut (Surya, 2004), remunerasi adalah sesuatu yang diterima pegawai sebagai imbalan dari kontribusi kinerja yang dihasilkan untuk organisasinya. Hal ini dilakukan untuk memacu terus kinerja dari para pegawainya. Pemberian remunerasi sangat penting bagi pegawai guna merangsang seseorang untuk melakukan pekerjaan melebihi apa yang diinginkan oleh organisasi. Remunerasi juga berfungsi sebagai penghargaan dari pegawai yang telah melakukan suatu pekerjaan yang telah ditetapkan oleh organisasi. Remunerasi merupakan cara yang paling sukses dalam meningkatkan kinerja pegawai karena berhubungan langsung antara kinerja dan imbalan. Remunerasi diidentifikasi sebagai salah satu faktor yang berpengaruh juga terhadap kepuasan kerja pegawai. Oleh karena itu, menarik bagi penulis untuk meneliti lebih jauh apakah upaya peningkatan kinerja pegawai di Polin ATMI cukup hanya dengan memperhatikan remunerasi saja atau melihat juga pada work passion dan motivasi seseorang. Dari fenomena di atas sebenarnya penulis hendak menguji lebih jauh apakah peningkatan kinerja pegawai Polin ATMI dipengaruhi langsung oleh work passion, motivasi, atau remunerasi. Atau motivasi dan remunerasi dapat menjadi mediasi terhadap peningkatan kinerja.

\section{TINJAUAN PUSTAKA}

Penelitian tentang work passion tetap menjadi topik yang menarik dan penting. Meski pada umumnya orang menghubungkan passion dengan aktivitas non-kerja seperti olahraga atau hobi, para peneliti maupun praktisi organisasi tetap mencatat pentingnya work passion. Seperti dikatakan Valerand, work passion adalah kecenderungan yang kuat dalam diri seseorang terhadap pekerjaan yang disukai dan dianggap penting, sehingga dirinya bersedia memberikan waktu dan energinya untuk pekerjaan tersebut (Vallerand et al., 2007). Dalam pengertian yang sederhana work passion adalah semangat yang besar disertai emosi yang kuat, hasrat yang membara, dan determinasi untuk mewujudkan suatu tujuan yang telah ditetapkan. (Houlfort, R. \& Vallerand, 2003) menyatakan ada 2 proses internalisasi passion dalam konteks kerja, yaitu obsessive passion dan harmonious passiont (Vallerand et al., 2003).

Obsessive passion adalah passion terhadap suatu kegiatan yang didapat dari sebuah tekanan internal atau eksternal seperti kebutuhan untuk diterima secara sosial, harga diri, penghargaan, atau bahkan kesenangan yang tidak terkedali (Vallerand et al., 2007). Sedangkan harmonious passion merupakan passion yang mengacu pada dorongan motivasional yang mengarahkan seseorang untuk terlibat secara sukarela terhadap aktivitas yang menjadi passion-nya. Di sini seseorang dengan bebas mencurahkan waktu dan energi untuk passion-nya sambil tetap mengendalikan dirinya terhadap aktivitas lainnya. Harmonious passion sendiri memiliki pengaruh positif 
terhadap kesehatan fisik, harga diri (self esteem), emosi positif, dan kreativitas seseorang. Dari pemahaman ini kita dapat melihat pentingnya work passion. (Yahui \& Jian, 2015) mengatakan bahwa work passion adalah konsep yang positif dan topik penelitian yang bernilai tinggi karena berkorelasi positif terhadap kepuasan kerja, komitmen, dan kinerja.

Motivasi berasal dari bahasa latin "movere" yang mengandung arti mendorong. Konsep motivasi ini menjadi penting dalam studi tentang kinerja karena motivasi dapat dimengerti sebagai faktor yang mendorong seseorang untuk bertindak dengan cara tertentu. (Hasibuan, 2013) mengatakan bahwa motivasi adalah pemberian daya penggerak yang menciptakan kegairahan kerja bagi seseorang sehingga orang tersebut mau bekerja sama, bekerja efektif, dan terintegrasi dengan segala daya upayanya untuk mencapai kepuasan. Pemberian motivasi kepada pegawai memiliki beberapa tujuan, yaitu: mendorong pegawai untuk bekerja lebih bersemangat, meningkatkan kepuasan kerja pegawai, meningkatkan kedisiplinan, menciptakan kondisi dan hubungan kerja yang baik, dan meningkatkan rasa tanggung jawab terhadap tugastugas yang dikerjakan. Seorang pemimpin perlu memahami perilaku anak buahnya agar dapat mempengaruhinya untuk bekerja sesuai tujuan organisasi (Handoko, 2002). Menurut McClelland, ada 3 motivasi utama manusia dalam bekerja, yaitu: motivasi untuk berprestasi (need of achievement), motivasi untuk berkuasa (need of power), dan motivasi untuk berafiliasi (need of affiliation) (Nelson, J. \& Quick, 2011). Pemberian motivasi yang tepat akan meningkatkan produktivitas, sebaliknya jika tidak tepat akan menimbulkan demotivasi dan membuang banyak sumber daya. Pemimpin organisasi harus memperhatikan motivasi dan menjadi sebuah kesadaran untuk selalu mengarahkan perilaku pegawainya mencapai tujuan organisasi yang ditetapkan.

Remunerasi selalu dapat diartikan dengan penggajian (payment). Istilah remunerasi biasanya diperuntukkan untuk pengupahan pegawai instansi pemerintah, namun pada dasarnya tetap sama bagi perusahaan karena tujuannya memberikan kesejahteraan kepada para karyawannya. (Surya, 2004) menegaskan bahwa remunerasi mempunyai pengertian berupa sesuatu yang diterima oleh pegawai sebagai imbalan dari kontribusinya kepada organisasi tempat bekerja. Remunerasi mempunyai makna lebih luas dari pada gaji karena mencakup semua bentuk imbalan, baik yang berbentuk uang maupun barang, yang diberikan secara langsung maupun tidak langsung, dan bersifat rutin maupun tidak rutin. Remunerasi adalah salah satu faktor yang mempengaruhi kinerja pegawai dalam menjalankan tugasnya. Menurut (Samsudin, 2007), tujuan pemberian remunerasi, antara lain: pemenuhan kebutuhan ekonomi pegawai, memberikan keseimbangan dan keadilan, mendorong pegawai untuk memajukan organisasi, dan meningkatkan produktivitas kerja. Sedangkan (Hasibuan, 2013) mengemukakan bahwa pemberian remunerasi mempunyai beberapa tujuan, yaitu: menciptakan ikatan kerjasama antara pegawai dengan pemberi kerja, memberikan kepuasan kerja, meningkatkan motivasi, menjaga stabilitas pegawai, dan 
meningkatkan disiplin pegawai, memberikan pengaruh yang baik kepada serikatserikat pekerja yang ada, dan menghindari intervensi pemerintah.

Kinerja merupakan faktor yang penting bagi sebuah organisasi. Peningkatan kinerja pegawai akan berdampak positif bagi kesuksesan organisasi. Kinerja adalah suatu hasil kerja yang dicapai seseorang dalam melaksanakan tugas-tugas yang diberikan kepadanya. (Mangkunegara, 2003) mengemukakan bahwa pengertian kinerja adalah hasil secara kualitas dan kuantitas yang dicapai seorang pegawai dalam melaksanakan tugasnya sesuai dengan tanggung jawab yang diberikan kepadanya berdasarkan kemampuan, pengalaman, keseriusan, dan waktu penyelesaian. Sedangkan (Prawirosentono, 2008) melengkapi lebih tajam bahwa kinerja adalah hasil kerja yang diperoleh dari orang atau kelompok di dalam organisasi sesuai dengan kekuatan masing-masing yang bertanggung jawab mencapai target organisasi secara legal dan tidak melanggar hukum, moral, dan etika.

Beberapa faktor yang dapat digunakan untuk mengukur kinerja pegawai yaitu tingkat kualitas hasil kerja, tingkat keuletan, daya tahan kerja, tingkat disiplin, presensi, tingkat kerjasama antar rekan sekerja, tingkat kepedulian akan keselamatan kerja, tingkat tanggung jawab atas hasil pekerjaan, dan tingkat inisiatif atau kreativitas yang dimiliki. Sedangkan tolok ukur kinerja menurut (Dharma, 2003), antara lain: kuantitas, kualitas, dan ketepatan waktu. Kuantitas adalah jumlah yang harus dicapai. Kualitas dipahami sebagai mutu yang harus dihasilkan dengan baik. Sedangkan ketepatan waktu adalah sesuai atau tidaknya hasil yang diselesaikan dengan waktu yang direncanakan.

Peningkatan kinerja selalu menjadi isu yang penting di dalam organisasi karena kinerja berkontribusi bagi keberhasilan organisasi tersebut. Penelitian yang melihat hubungan work passion terhadap motivasi dilakukan (Stoeber et al., 2011) pada 105 mahasiswa di Inggris. Dalam penelitian yang berjudul "Passion and Motivation for Studying: Predicting Academic Engagement and Burnout in University Students" ini meneliti hubungan harmonius passion dan obsessive passion terhadap keterlibatan akademik (academic engagement) dan rasa jenuh (burnout) yang terjadi pada mahasiswa dan pengaruhnya terhadap autonomous motivation dan controlled motivation mahasiswa. Hasil penelitian ini menunjukkan bahwa harmonious passion memberikan pengaruh yang positif terhadap autonomous motivation, academic engagement (khususnya vigour dan dedication), dan berpengaruh negatif terhadap rasa jenuh yang muncul karena perasaan sinis (cynicism) dan tidak yakin (inefficacy). Artinya, bila work passion mengalami peningkatakan maka akan memberikan pengaruh yang dapat meningkatkan pula motivasi otonomi mahasiswa dan keterlibatan akademiknya, sekaligus menurunkan perasaan jenuh mereka.

Berdasarkan teori dan penelitian sebelumnya, maka hipotesa penelitian yang diajukan penulis adalah:

H1 : Work Passion dapat berpengaruh signifikan terhadap Motivasi.

H2 : Work Passion dapat berpengaruh signifikan terhadap Remunerasi. 
Penelitian yang dilakukan (Juliani \& Purba, 2019) dengan judul "The Mediating Role of Passion for Work on the Relationship between Task Significance and Performance" melihat hubungan signifikansi tugas (task significance), work passion, dan kinerja ini. Signifikansi tugas sendiri mempunyai pengertian bahwa pekerjaan yang dilakukan memiliki makna dan dampak terhadap hidup orang lain baik di dalam maupun di luar organisasi. Penelitian yang dilakukan terhadap 434 tenaga kerja kesehatan pada Organisasi Jaminan Kesehatan Nasional milik pemerintah ini menunjukkan bahwa secara parsial signifikansi tugas secara positif berkorelasi dengan work passion dan kinerja. Di dalam penelitian ini dihasilkan juga bahwa hanya harmonious passion yang dapat berperan sebagai mediasi di dalam pengaruh signifikansi tugas terhadap kinerja, sedangkan obsessive passion tidak dapat memediasi hubungan ini.

Hal serupa ditemukan juga di dalam penelitian yang dilakukan oleh (Qadeer et al., 2016) dengan judul "Linking Passion to Organizational Citizenship Behavior and Employee Performance: The Mediating Role of Work Engagement". Penelitian yang dilakukan terhadap 210 karyawan tetap dan 27 manager di sebuah bank besar di Pakistan ini hendak menguji secara empiris bagaimana harmonious passion memiliki dampak terhadap kinerja dan perilaku ekstra karyawan dalam berorganisasi (OCB) dengan dimediasi oleh peranan keterlibatan kerja (work engagement). Dari penelitian itu dihasilkan bukti empiris bahwa harmonious passion secara langsung berpengaruh positif terhadap kinerja karyawan. Secara umum harmonius passion dapat menciptakan energi yang tinggi dan memberikan tujuan bagi keterlibatan kerja sehingga dapat meningkatkan kinerja dan perilaku OCB karyawan.

Hipotesa penelitian yang didapatkan dari rumusan teori di atas adalah sebagai berikut:

\section{H3 : Work Passion dapat berpengaruh signifikan terhadap Kinerja.}

Sedangkan penelitian yang menguji pengaruh motivasi terhadap kinerja dapat dilihat pada tulisan (Jasiyah, 2018) yang berjudul "The Effect of Ability and Motivation on Job Satisfaction and Employee Performance". Penelitian ini dilakukan terhadap 220 pegawai di sebuah Kantor Regional Direktorat Jenderal Perbendaharaan, Kementrian Keuangan RI di Sulawesi Tenggara. Dalam penelitian ini, mereka ingin menganalisa pengaruh kemampuan dan motivasi terhadap kinerja pegawai dengan job satisfaction sebagai mediasi. Hasil penelitian menyatakan bahwa secara parsial motivasi mempunyai pengaruh langsung yang positif terhadap kinerja pegawai. Motivasi adalah sebuah cara untuk mencapai suatu tujuan. Bila pegawai memiliki motivasi yang tinggi maka mereka akan mempunyai keinginan kuat untuk meningkatkan kinerjanya.

Dari pandangan peneliti di atas, maka hipotesa penelitian yang dapat diajukan adalah:

\section{H4 : Motivasi dapat berpengaruh signifikan terhadap Kinerja.}

Penelitian tentang pengaruh remunerasi terhadap kinerja telah banyak dilakukan. Dalam penelitian-penelitian tersebut selalu ditemukan sebuah hubungan pengaruh yang positif. Di dalam penelitian yang berjudul "Remuneration Reward 
Management System as A Driven Factor of Employee Performance" yang ditulis oleh (Martono et al., 2018) dihasilkan bahwa remunerasi mempunyai pengaruh yang positif terhadap kinerja. Penelitian yang dilakukan terhadap 403 pegawai tetap Universitas Negeri Semarang ini untuk menganalisa pengaruh remunerasi, motivasi, job satisfaction, baik secara langsung atau tidak langsung terhadap kinerja pegawai. Dikatakan bahwa remunerasi dan job satisfaction adalah 2 faktor yang penting di dalam peningkatan kinerja individu dan pengaruh remunerasi terhadap kinerja juga harus melalui mediasi motivasi dan job satisfaction.

Berdasarkan penelitian sebelumnya, maka hipotesa penelitian yang diajukan adalah:

\section{H5 : Remunerasi dapat berpengaruh signifikan terhadap Kinerja.}

Penelitian yang menguji efek motivasi sebagai mediasi di dalam pengaruh work passion terhadap kinerja dapat dilihat juga pada penelitian yang dilakukan oleh (Supriadi et al., 2018) yang berjudul "The Effect of Competence and Organization Culture to Employee Performance with Motivation as The Mediation Variable in The Directorate General of Fiscal Balance-Ministry Finance, Indonesia". Penelitian yang dilakukan terhadap 426 pegawai negeri yang bekerja di Direktorat Jenderal Fiskal, hendak menganalisa pengaruh kompetensi dan budaya organisasi terhadap kinerja pegawai melalui motivasi sebagai variabel mediasi. Penulis sendiri melihat bahwa kompetensi dapat menjadi hasil dari sebuah passion karena kompetensi merupakan kemampuan untuk mengintegrasikan pengetahuan, keterampilan (skill), sikap (attitude), nilai personal, dan kemampuan untuk membangun pengetahuan dan ketrampilan berdasarkan pengalaman dan pembelajaran yang terus dilakukan (Roe R., 2002). Hasil penelitian ini menyatakan bahwa motivasi dapat memberikan efek tidak langsung (mediasi) di dalam pengaruh kompetensi terhadap kinerja. Namun demikian, pengaruh mediasi yang diberikan tidak terlalu efektif karena masih lebih besar pengaruh langsungnya.

Berdasarkan teori dan penelitian sebelumnya, maka hipotesa penelitian yang diajukan penulis adalah:

H6 : Motivasi dapat memediasi pengaruh Work Passion terhadap Kinerja.

H7 : Remunerasi dapat memediasi pengaruh Work Passion terhadap Kinerja.

Dari uraian teori dan hasil penelitian sebelumnya yang mendukung hipotesis penelitian penulis, maka diusulkan suatu model penelitian sebagai kerangka konseptual tentang kinerja dapat dipengaruhi work passion dan dimediasi oleh motivasi dan remunerasi. Kerangka konseptual tersaji sebagai berikut: 


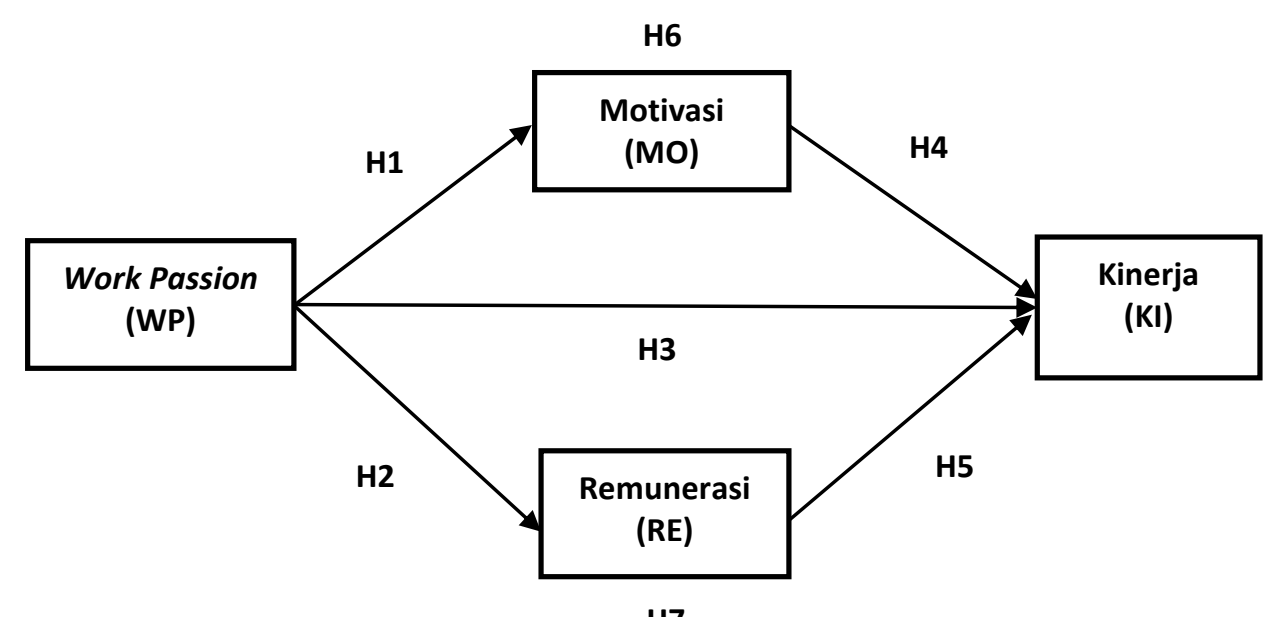

H7

Gambar 1. Kerangka Konseptual

\section{METODE PENELITIAN}

Dalam penelitian ini penulis menggunakan teknik pengambilan sampel nonprobality sampling dengan teknik sampel jenuh. Responden penelitian adalah seluruh pegawai Polin ATMI. Teknik pengumpulan data dilakukan melalui penyebaran kuesioner dengan menggunakan google form. Jumlah kuesioner yang dibagikan sebanyak 71 responden yang merupakan pegawai tetap. Dari 71 kuesioner yang dibagikan hanya 69 yang mengembalikan dan dapat digunakan.

Dalam kuesioner penulis menggunakan Skala Likert untuk mengukur sikap, pendapat, dan persepsi dari masing-masing pegawai terhadap situasi atau fenomena sosial. Fenomena yang telah ditetapkan oleh peneliti disebut sebagai variabel penelitian dan dijabarkan dalam dimensi-dimensi variabel (Supranto, 2009). Dimensidimensi variabel tersebut dijadikan titik tolak dalam penyusunan indikator-indikator pernyataan atau pertanyaan. Dalam penelitian ini, tanggapan atas pertanyaan dinyatakan dalam 6 pilihan jawaban, yaitu: sangat setuju (6), setuju (5), cukup setuju (4), agak tidak setuju (3), tidak setuju (2), dan sangat tidak setuju (1). Dari pengolahan hasil kuesioner ini dapat dihasilkan data statistik deskriptif tentang karakteristik responden.

Variabel Work Passion (WP) dikembangkan oleh (Vallerand et al., 2003) dengan 3 dimensi, yaitu: harmonious passion, obsessive passion, ditambah additional passion, dengan 15 indikator instrumen. Salah satu contoh indikator dalam dimensi harmonious passion misalnya "saya sangat menghargai hal-hal baru yang saya temukan dari pekerjaan ini". Untuk Variabel Motivasi (MO) dikembangkan oleh McClleland (Hasibuan, 2013) dengan 3 dimensi, yaitu: motivasi untuk berprestasi (need of achievement), motivasi untuk berkuasa (need of power), dan motivasi untuk berafiliasi (need of affiliation), dengan 12 indikator instrumen. Contoh indikator dari dimensi need of affiliation adalah "saya berkeinginan untuk membina persahabatan dengan orang lain, memperbaikinya, atau memeliharanya". Sedangkan Variabel Remunerasi (RE) dikembangkan oleh (Santoso, 2012), dengan 5 dimensi, yaitu: sistem merit 
(berdasarkan kinerja), adil (proporsional dan objektif), layak (wajar dan sesuai ketentuan normatif), kompetitif (sesuai dengan pekerjaan yang dipersyaratkan), dan transparan (terbuka dan mudah dipahami), dengan 9 indikator instrumen.

Pertanyaan indikator yang tercantum dalam kuesioner untuk dimensi transparan misalnya "saya mengetahui dengan baik komponen-komponen remunerasi yang saya terima selama bekerja ini". Terakhir, Variabel Kinerja (KI) dengan 5 dimensi, yaitu: komitmen terhadap organisasi, unsur kepribadian, sikap kerja, kemampuan bekerja, dan kemampuan manajerial, dengan 20 indikator instrumen. Dimensi-dimensi dari variabel Kinerja ini diambil dari Penilaian Kinerja Polin ATMI. Pertanyaan indikator yang tercantum dalam kuesioner untuk dimensi sikap kerja adalah "saya selalu masuk kerja sesuai dengan jadwal yang ditetapkan institusi kepada saya".

Sebelum pengujian hipotesis dilakukan, penulis melakukan uji validitas dan reliabilitas untuk mengetahui ketepatan dan kevalidan alat ukur kuesioner yang digunakan. Untuk pengujian terhadap hipotesis penelitian, penulis menggunakan SPSS V.23 dan Macro Hayes 2013 karena penulis akan menggunakan multi mediasi yaitu variabel motivasi dan remunerasi. Selanjutnya, penulis juga akan menggunakan mean score dan overall mean score untuk melakukan analisa dan kajian deskriptif.

\section{HASIL PENELITIAN}

Tabel 1. Karakteristik Responden

\begin{tabular}{|c|c|c|c|}
\hline Variabel & Kategori & Frekuensi & $\%$ \\
\hline \multirow{2}{*}{ Jenis Kelamin } & Laki-laki & 51 & 73,9 \\
\hline & Perempuan & 18 & 26,1 \\
\hline \multirow{2}{*}{ Status Fungsional } & Tenaga Pengajar & 47 & 68,1 \\
\hline & Tenaga Kependidikan & 22 & 31,9 \\
\hline \multirow{7}{*}{ Usia } & di bawah $25-25$ tahun & 13 & 18,8 \\
\hline & di atas $25-30$ tahun & 24 & 34,8 \\
\hline & di atas $30-35$ tahun & 17 & 24,6 \\
\hline & di atas $35-40$ tahun & 7 & 10,1 \\
\hline & di atas $40-45$ tahun & 1 & 1,4 \\
\hline & di atas $45-50$ tahun & 6 & 8,7 \\
\hline & di atas 50 tahun & 1 & 1,4 \\
\hline \multirow[t]{5}{*}{ Masa Kerja } & di bawah $1-1$ tahun & 4 & 5,8 \\
\hline & di atas $1-5$ tahun & 29 & 42,0 \\
\hline & di atas $5-10$ tahun & 25 & 36,2 \\
\hline & di atas $10-15$ tahun & 7 & 10,1 \\
\hline & di atas 15 tahun & 4 & 5,8 \\
\hline
\end{tabular}

Sumber: Data Primer dari Program SPSS V. 23 (2020)

Dari Tabel 1 dapat dirangkum bahwa mayoritas responden penelitian ini adalah laki-laki sebanyak 51 orang (73,9\%). Usia dominan responden di atas 25-30 tahun sebanyak 24 orang $(34,8 \%)$ dan disusul usia di atas 30-35 tahun sejumlah 17 orang $(24,6 \%)$. Untuk status fungsional responden kebanyakan tenaga pengajar sejumlah 47 orang $(68,1 \%)$ dengan masa kerja yang paling banyak adalah yang bekerja di atas 1 
sampai 5 tahun yang berjumlah 29 orang (42\%) dan masa kerja di atas 5 sampai 10 tahun yaitu 25 orang $(36,2 \%)$.

Untuk hasil uji analisis data dan validitas adalah sebagai berikut:

Tabel 2. Hasil Uji Analisis Data dan Validitas

\begin{tabular}{|c|c|c|c|c|c|}
\hline $\begin{array}{l}\text { Variabel / } \\
\text { Dimensi }\end{array}$ & Indikator & $\begin{array}{l}\text { Mean } \\
\text { Score }\end{array}$ & $\begin{array}{l}\text { Overall } \\
\text { Mean } \\
\text { Score }\end{array}$ & $\begin{array}{c}\text { Cronbach } \\
\text { Alpha } \\
\text { (Reliability) }\end{array}$ & $\begin{array}{c}\text { Corrected } \\
\text { Item Total } \\
\text { Corelation } \\
\text { (Validity) }\end{array}$ \\
\hline WP & & & 4,04 & 0,892 & \\
\hline \multirow[t]{4}{*}{ Additional $P$. } & Passion & 4,28 & 4,45 & & 0,748 \\
\hline & Like & 4,46 & & & 0,785 \\
\hline & Important & 4,83 & & & 0,630 \\
\hline & Effect and control & 4,22 & & & 0,261 \\
\hline \multirow[t]{5}{*}{ Harmonious $P$. } & Harmony with my activities & 3,67 & 4,16 & & 0,553 \\
\hline & Loss control & 3,19 & & & 0,241 \\
\hline & New things & 5,13 & & & 0,312 \\
\hline & Deep attention & 4,42 & & & 0,783 \\
\hline & My quality & 4,39 & & & 0,710 \\
\hline \multirow[t]{6}{*}{ Obssesive $P$. } & Gain experience & 4,77 & 3,66 & & 0,635 \\
\hline & Change & 3,45 & & & 0,499 \\
\hline & Integrated & 3,97 & & & 0,771 \\
\hline & Do my work & 3,00 & & & 0,433 \\
\hline & Harmony with other things & 3,74 & & & 0,682 \\
\hline & Exciting & 3,06 & & & 0,462 \\
\hline MO & & & 4,61 & 0,847 & \\
\hline \multirow[t]{4}{*}{ N. Achievement } & Fulfill better results & 5,03 & 4,84 & & 0,508 \\
\hline & The job with challenges & 4,74 & & & 0,534 \\
\hline & Responsibility to solve a problem & 4,72 & & & 0,511 \\
\hline & Realistic with the goals & 4,86 & & & 0,518 \\
\hline \multirow[t]{4}{*}{ N. Power } & The others impres me & 4,22 & 3,90 & & 0,468 \\
\hline & Influence the others & 3,48 & & & 0,512 \\
\hline & Competitive situations & 4,10 & & & 0,542 \\
\hline & Control over events & 3,80 & & & 0,495 \\
\hline \multirow[t]{4}{*}{ N. Affiliation } & Friendships with others & 5,29 & 5,10 & & 0,540 \\
\hline & Work together & 4,57 & & & 0,550 \\
\hline & Socialize with anyone & 5,26 & & & 0,630 \\
\hline & Enjoy with my colleagues & 5,29 & & & 0,545 \\
\hline RE & & & 3,62 & 0,866 & \\
\hline \multirow{2}{*}{ Merit System } & Based on the workload & 3,80 & 3,72 & & 0,688 \\
\hline & Based on the performance & 3,65 & & & 0,787 \\
\hline Fair & $\begin{array}{l}\text { Wages by higher knowledge, skills, } \\
\text { and responsibilities }\end{array}$ & 3,68 & 3,68 & & 0,692 \\
\hline \multirow{2}{*}{ Worthy } & Enough to meet my needs & 3,46 & 3,42 & & 0,608 \\
\hline & Can improve my welfare & 3,38 & & & 0,776 \\
\hline \multirow[t]{2}{*}{ Competitive } & Equivalent with other institutions & 2,96 & 3,42 & & 0,725 \\
\hline & Feel at home working to be here & 3,88 & & & 0,298 \\
\hline \multirow[t]{2}{*}{ Transparent } & Know the components & 3,83 & 3,88 & & 0,345 \\
\hline & $\begin{array}{l}\text { Know the process of cutting } \\
\text { income }\end{array}$ & 3,93 & & & 0,489 \\
\hline KI & & & 4,59 & 0,921 & \\
\hline \multirow[t]{2}{*}{ Org. Commitment } & Vision, mission, \& values & 4,55 & 4,40 & & 0,626 \\
\hline & Willing to do additional tasks & 4,25 & & & 0,470 \\
\hline \multirow[t]{4}{*}{ Personality } & Prioritize cooperation & 4,96 & 4,78 & & 0,530 \\
\hline & $\begin{array}{l}\text { Report work, give advice, \& carry } \\
\text { out work instructions }\end{array}$ & 4,74 & & & 0,642 \\
\hline & Fulfill the rules properly & 4,91 & & & 0,669 \\
\hline & Finish the tasks and work on time & 4,52 & & & 0,582 \\
\hline
\end{tabular}




\begin{tabular}{|c|c|c|c|c|c|}
\hline $\begin{array}{l}\text { Variabel / } \\
\text { Dimensi }\end{array}$ & Indikator & $\begin{array}{l}\text { Mean } \\
\text { Score }\end{array}$ & $\begin{array}{l}\text { Overall } \\
\text { Mean } \\
\text { Score }\end{array}$ & $\begin{array}{c}\text { Cronbach } \\
\text { Alpha } \\
\text { (Reliability) }\end{array}$ & $\begin{array}{c}\text { Corrected } \\
\text { Item Total } \\
\text { Corelation } \\
\text { (Validity) }\end{array}$ \\
\hline \multirow[t]{5}{*}{ Work attitude } & Come to work on schedule & 5,07 & 4,76 & & 0,524 \\
\hline & Come to work or meetings on time & 4,71 & & & 0,390 \\
\hline & Work independently & 4,94 & & & 0,640 \\
\hline & Always reach the target work & 4,54 & & & 0,628 \\
\hline & Achieve the quality standards & 4,52 & & & 0,697 \\
\hline \multirow[t]{4}{*}{ Working Ability } & have the technical knowledge & 4,65 & 4,64 & & 0,566 \\
\hline & work effectively & 4,59 & & & 0,654 \\
\hline & $\begin{array}{l}\text { clean up and maintain my work } \\
\text { equipment and workplace }\end{array}$ & 4,84 & & & 0,597 \\
\hline & $\begin{array}{l}\text { come up with ideas and new } \\
\text { breakthroughs }\end{array}$ & 4,46 & & & 0,565 \\
\hline \multirow[t]{5}{*}{ Managerial Ability } & $\begin{array}{l}\text { Do the planning, supervision, \& } \\
\text { evaluation }\end{array}$ & 4,59 & 4,31 & & 0,756 \\
\hline & Motivate my colleagues & 4,45 & & & 0,632 \\
\hline & Provide work problem solving & 4,13 & & & 0,523 \\
\hline & Dare to make choices \& decisions & 4,33 & & & 0,590 \\
\hline & $\begin{array}{l}\text { Able to direct, lead, \& inspire } \\
\text { others }\end{array}$ & 4,04 & & & 0,548 \\
\hline
\end{tabular}

Sumber: Data Primer dari Program SPSS V. 23 (2020)

Sebagaimana tersaji dalam Tabel 2, nilai cronbach's alpha dari kelompok variabel work passion, motivasi, remunerasi, dan kinerja adalah 0,892;0,847; 0,866; dan 0,921. Karena nilai-nilai ini lebih besar (>) dari 0,60, maka semua variabel dikatakan reliabel. Demikian juga dengan hasil uji statistiknya yang menunjukkan bahwa semua indikator pernyataan memiliki corrected item-total correlation lebih besar (>) dari 0,196 (r-tabel). Artinya, semua indikator pernyataan dikatakan valid untuk mengukur variabel work passion, motivasi, remunerasi, dan kinerja.

Untuk mengetahui kategori jawaban responden, penulis menggunakan rentang skala atau interval dengan rumus RS $=(N T-N R) / K$, dimana RS adalah Rentang Skala, NT adalah Nilai Tertinggi, NR adalah Nilai Terendah, dan K adalah Jumlah Kategori. RS = (6$1) / 6=0,833$. Rentang skala dari kategori jawaban responden tersaji sebagai berikut:

Tabel 3. Rentang Skala Kategori Jawaban Responden

\begin{tabular}{cc}
\hline Rentang Skala & Tingkat Hubungan \\
\hline $5,16-6,00$ & Sangat Tinggi \\
\hline $4,33-5,15$ & Tinggi \\
\hline $3,50-4,32$ & Cukup \\
\hline $2,67-3,49$ & Agak Rendah \\
\hline $1,84-2,66$ & Rendah \\
\hline $1,00-1,83$ & Sangat Rendah \\
\hline
\end{tabular}

Sumber: Pengolahan Data Penulis (2020)

Dari jawaban-jawaban responden sebagaimana tersaji dalam kuesioner menunjukkan bahwa para pegawai Polin ATMI memiliki tingkat Work Passion (WP) cukup dengan nilai rata-rata 4,04 dari 6. Dimensi yang terendah dari WP adalah dimensi obssesive passion dengan nilai 3,66 (cukup) dari 6 dan yang tertinggi adalah 
adalah dimensi additional passion dengan nilai 4,45 (tinggi). Indikator yang paling tinggi dari dimensi additional passion adalah "pekerjaan ini penting bagi saya" dengan nilai 4,83 (tinggi). Yang menarik adalah indikator yang menyatakan bahwa "pekerjaan yang saya lakukan saat ini merupakan passion dari diri saya" hanya bernilai 4,28 (cukup). Dapat dikatakan bahwa meskipun pekerjaan yang dilakukan saat ini belum menjadi passion-nya, namun para pegawai mengakui bahwa pekerjaan yang dilakukan sekarang adalah pekerjaan yang penting bagi dirinya. Dari semua indikator di dalam variabel ini yang paling tinggi adalah "saya sangat menghargai hal-hal baru yang ditemukan dari pekerjaan ini" dengan nilai 5,13 (baik). Jadi dapat dipersepsikan bahwa pegawai melakukan pekerjaan saat ini karena adanya hal-hal baru yang dapat ditemukan di dalam pekerjaannya. Sedangkan indikator yang paling rendah pada variabel ini adalah "saya hanya akan melakukan pekerjaan ini" dengan nilai 3,00 (agak rendah). Dari fakta itu dapat disimpulkan bahwa pekerjaan saat ini memang belum menjadi passion-nya, namun pekerjaan yang dilakukan itu tetap menjadi hal yang penting dalam dirinya dan mereka sangat menghargai hal-hal baru yang mungkin didapatkan dari pekerjaan tersebut. Mereka sendiri juga mempersepsikan bahwa dirinya belum tentu akan terus melakukan pekerjaan yang dilakukan saat ini. Bisa jadi demikian karena para pegawai masih banyak berusia muda (di atas 25 sampai 30 tahun) dan masa kerjanya kebanyakan masih antara 1 sampai 5 tahun.

Untuk variabel motivasi (MO) dipersepsikan baik karena nilai rata-ratanya hanya 4,61 dari 6 . Dimensi yang terendah adalah dimensi motivasi untuk berkuasa dengan skor 3,90 (cukup), sedangkan yang paling tinggi adalah dimensi motivasi untuk berafiliasi dengan skor 5,10 (sangat baik). Indikator paling rendah pada variabel motivasi ini adalah "saya senang mempengaruhi orang lain untuk memperoleh keinginan saya" dengan nilai 3,48 (agak rendah) dan indikator yang paling tinggi dari variabel motivasi adalah "saya berkeinginan untuk membina persahabatan dengan orang lain, memperbaikinya atau memeliharanya" dan "saya senang bersosialisai dengan rekan-rekan kerja bagian saya" dengan nilai 5,29 (sangat baik). Meskipun dimensi motivasi untuk berprestasi nilainya 4,84 (baik), namun yang paling memotivasi adalah motivasi untuk berafiliasi dan bersosialisasi dengan rekan-rekan kerjanya. Dengan demikian, bisa jadi motivasi yang paling dominan dari para pegawai Polin ATMI adalah need of affiliation bukan need of achievement, apalagi need of power.

Persepsi responden untuk variabel Remunerasi (RE) adalah cukup karena nilai rata-ratanya adalah 3,62 dari 6 . Dari variabel ini, nilai terendah terletak pada dimensi kelayakan dan kompetitif dengan nilai 3,42 (agak rendah). Sedangkan dimensi yang paling tinggi adalah dimensi transparansi dengan nilai 3,88 (cukup). Indikator yang paling tinggi pada variabel remunerasi ini adalah "saya mengetahui dengan pasti bagaimana proses pemotongan remunerasi (penghasilan) dilakukan" dengan nilai 3,92 (cukup). Sedangkan indikator yang paling rendah pada variabel ini adalah "saya merasa bahwa remunerasi yang diberikan kepada saya setara dengan remunerasi institusi lain dengan kualifikasi yang sama dengan saya", dengan nilai 2,96 (agak rendah). Dengan 
demikian dapat dipersepsikan bahwa secara umum pegawai Polin ATMI cukup baik dalam menerima remunerasi dari sisi transparasi karena menjadi nilai yang paling tinggi. Namun, pegawai Polin ATMI masih merasa kurang baik dalam hal kelayakan dan tingkat kompetitif remunerasi yang diterima. Mereka masih merasa bahwa remunerasi yang diterima masih belum setara dengan institusi lain dengan kualifikasi yang sama.

Sedangkan persepsi responden terhadap variabel kinerja adalah baik, dengan nilai 4,53 dari 6 . Dimensi paling rendah adalah dimensi kemampuan manajerial, yang nilainya 4,31 (cukup) dan dimensi yang paling tinggi adalah dimensi kepribadian dengan nilai 4,78 (baik). Indikator yang paling rendah dari variabel kinerja ada pada indikator dengan pernyataan "saya mampu mengarahkan, memimpin, dan menginspirasi orang lain untuk bekerja sesuai dengan tujuan yang ditentukan" dengan nilai 4,04 (cukup) dari 6. Sedangkan indikator yang paling tinggi adalah "saya selalu masuk kerja sesuai dengan jadwal yang ditetapkan institusi kepada saya" dengan nilai 5,07 (baik). Hal ini mengindikasikan bahwa tingkat kinerja para pegawai Polin ATMI baik dilihat dari sisi kepribadian para pegawainya. Yang harus ditingkatkan lebih baik lagi adalah kemampuan manajerial para pegawainya untuk memacu tingkat kinerja organisasi. Bila ditelusuri lebih jauh dari masing-masing dimensinya tingkat kinerja pegawai Polin ATMI sudah baik (komitmen, kepribadian, sikap kerja, dan kemampuan bekerja). Yang masih ditingkatkan lagi adalah kemampuan manajerial dan tingkat loyalitas para pegawainya.

\section{PEMBAHASAN}

Sebagaimana tersaji pada Tabel 4 di atas diperoleh hasil hipotesis 1 yaitu work passion dapat berpengaruh signifikan meningkatkan motivasi. Hal itu ditunjukkan dengan nilai $p$ (signifikansinya) $=0,000<0,05$. Artinya, responden mempersepsikan bila mereka bekerja sesuai dengan work passion-nya, maka akan meningkatkan motivasi mereka. Dari hasil pengujian tercatat pengaruh peningkatan yang diberikan sebesar $38,75 \%$. Pengujian ini sejalan dengan peneltian yang dilakukan (Stoeber et al., 2011) yang menunjukkan bahwa work passion memberikan pengaruh yang positif terhadap tingkat motivasi. Yang menarik, work passion yang memberikan pengaruh besar adalah harmonius passion. Dikatakan bahwa harmonious passion memberikan pengaruh yang positif terhadap autonomous motivation, academic engagement, dan berpengaruh negatif terhadap rasa jenuh (burn out). Hal itu sejalan dengan penelitian yang dilakukan ini, dimana indikator yang paling besar (mean score adalah 5,13 atau sangat tinggi) ada pada wilayah dimensi harmonius passion. Dengan demikian dapat dipersepsikan bahwa work passion yang meningkatkan motivasi pegawai Polin ATMI dipengaruhi cukup besar oleh harmonius passion. Di dalam pengujian work passion terhadap remunerasi didapatkan hasil bahwa work passion dapat berpengaruh signifikan terhadap remunerasi karena nilai $p=0,002<0,05$. Dengan demikian hipotesis 2 juga dapat diterima dengan koefisien regresi yang dihasilkan sebesar 29,5\%. Pengaruh ini dapat diterangkan melalui fakta empiris yang ditemukan dari persepsi 
responden sebelumnya yaitu kenyataan bahwa pegawai Polin ATMI menganggap penting pekerjaan yang dilakukan walaupun belum menjadi passion-nya dan menghargai hal-hal baru yang mungkin didapatkan dari pekerjaan itu. Sikap ini yang memberikan pengaruh bila dihubungkan dengan variabel remunerasi. Dengan mereka menerima pekerjaan yang memberikan hal-hal baru maka memungkinkan terjadinya peningkatan terhadap remunerasinya. Melalui fakta ini, maka dapat diterima bila work passion dapat berpengaruh terhadap peningkatan remunerasi.

Bila dilihat dalam gambar di atas ternyata hubungan work passion dengan kinerja tidak signifikan karena $p=0,698$ dan $p>0,05$. Artinya, work passion para pegawai Polin ATMI tidak dapat meningkatkan kinerjanya. Dengan demikian hipotesis 3 ini tidak terbukti. Dengan melihat hasil dari penelitian ini yang menemukan bahwa pekerjaan yang dilakukan belum sepenuhnya menjadi work passion pegawai, maka dapat dipahami bila work passion tidak memberikan pengaruh terhadap peningkatan kinerja. Sedangkan hubungan motivasi terhadap kinerja didapatkan pengaruh yang signifikan karena $p=0,000$. Dengan demikian hipotesis 4 ini dapat diterima dan koefisien regresinya sebesar $95,61 \%$. Penelitian ini sejalan dengan penelitian yang dilakukan (Jasiyah, 2018) yang membuktikan bahwa pegawai yang memiliki motivasi tinggi akan mempunyai keinginan kuat untuk meningkatkan kinerjanya. Di dalam penelitian ini juga terbukti bahwa pengaruh motivasi para pegawai mencapai 95,6\% terhadap kinerja. Dari semua variabel, motivasi memang menunjukkan nilai overall mean score yang paling tinggi sehingga dapat dipahami bila pengaruh motivasi tinggi. Untuk hubungan remunerasi dengan kinerja diperoleh hasil tidak signifikan karena $p=0,158>0,005$. Artinya, hipotesis 5 tidak terbukti. Yang menarik di dalam penelitian ini adalah remunerasi tidak memberikan pengaruh signifikan untuk meningkatkan kinerja. Peningkatan kinerja pegawai di Polin ATMI tidak semata-mata hanya dipengaruhi oleh remunerasi. Penelitian ini memang tidak sejalan dengan penelitian sebelumnya yang dilakukan (Martono et al., 2018). Di dalam penelitiannya menunjukkan bahwa remunerasi berpengaruh langsung terhadap kinerja, namun, pengaruh yang lebih besar bila dilakukan dengan mediasi motivasi dan job satisfaction. Penelitian sebelumnya yang sejalan ditemukan pada penelitian (Rahayu \& Ruhamak, 2017). Penelitian ini menunjukkan bahwa remunerasi tidak memberikan pengaruh signifikan terhadap kinerja karyawan. Pengaruh signifikan yang dapat meningkatkan kinerja adalah motivasi.

Penelitian pada hipotesis 6 didapatkan hasil yaitu motivasi terbukti signifikan memediasi pengaruh work passion terhadap kinerja karena BootLLCl=0,181 dan BootULCl=0,635 dan indirect effect-nya adalah 0,370 sehingga efek mediasi motivasi yang diberikan sebesar $37,0 \%$. Penelitian ini sejalan dengan penelitian yang dilakukan (Supriadi et al., 2018) yang menyatakan motivasi dapat memberikan efek tidak langsung di dalam pengaruh kompetensi sebagai hasil sebuah passion terhadap kinerja. Namun, dalam penelitian ini pengaruh mediasi yang diberikan juga tidak efektif karena pengaruh langsungnya (pengaruh motivasi terhadap kinerja) masih lebih 
besar. Sebaliknya efek remunerasi tidak dapat memberikan mediasi pada pengaruh work passion terhadap kinerja. Ini dapat dilihat dari BootLLCl= $-0,026$ dan BootULCI= 0,156 yang menunjukkan hipotesis 7 tidak terbukti. Dengan demikian variabel remunerasi tidak dapat memediasi pengaruh work passion terhadap kinerja. Bisa dikatakan, baik langsung atau tidak langsung variabel remunerasi tetap tidak memberikan peningkatan terhadap kinerja.

\section{KESIMPULAN DAN SARAN}

Dari hasil penelitian yang ditemukan dapat ditarik 2 kesimpulan yang paling dominan. Pertama, work passion tidak berpengaruh langsung terhadap peningkatan kinerja, namun berpengaruh langsung terhadap peningkatan motivasi dan remunerasi. Hal ini dapat terjadi karena pekerjaan yang dilakukan bukan merupakan passion-nya. Pegawai melakukan pekerjaan karena semata menghargai pekerjaan tersebut atau hanya dorongan kebutuhan internal. Oleh karena itu, pengaruh langsung yang terjadi sebatas motivasi untuk bekerja dan memperoleh upah atau remunerasi.

Sebaiknya pegawai bekerja sesuai dengan passion-nya sehingga mereka menaruh perhatian yang mendalam terhadap pekerjaannya dan mencerminkan kualitas diri mereka. Dalam hal ini institusi perlu meninjau kembali apa yang menjadi passion kerja para pegawainya dan disesuaikan dengan job design yang ada. Institusi perlu membangun suatu sistem pengukuran yang memastikan para pegawainya memiliki passion sesuai dengan bidang pekerjaannya. Dengan memperhatikan hal itu institusi memberi kesempatan kepada para pegawai untuk bekerja optimal, mengembangkan dirinya secara mandiri, dan semakin meningkatkan antusiasme kerja mereka, dan pada akhirnya menghasilkan tingkat kinerja yang diharapkan (Zigarmi et al., 2009).

Kedua, adanya pengaruh signifikan antara motivasi terhadap kinerja. Sedangkan remunerasi tidak memberikan pengaruh terhadap peningkatan kinerja. Dalam peningkatan motivasi, di sini peran atasan dalam meningkatkan motivasi pegawainya sangat penting dalam upaya mencapai kinerja yang baik. Kemampuan manajerial seorang atasan mutlak diperlukan karena peran mereka harus menjadi penggerak nilai-nlai, budaya, dan tujuan institusi. Oleh karena itu, kegiatan dalam rangka pembinaan dan pelatihan yang mengasah dan meningkatkan kemampuan manajerial para atasan harus menjadi perhatian institusi. Program pembinaan bagi para atasan ini perlu direncanakan, disusun, dan dikembangkan secara berkesinambungan. Dengan motivasi yang terjaga maka remunerasi bukan satusatunya cara untuk meningkatkan kinerja.

Selain itu institusi juga tetap perlu membuat program pendalaman motivasi bagi para pegawainya. Kegiatan awareness tentang visi, misi, values, dan corporate culture perlu dilakukan secara berkala lewat acara outing, rekoleksi, retret pegawai, role model, atau kegiatan reward dan apresiasi. Intinya institusi perlu melakukan proses pembudayaan dan penanaman nilai-nilai dalam berbagai bentuk yang dapat 
memberikan motivasi dan akhirnya meningkatkan kinerja seluruh pegawai. Dari penelitian ini dapat disimpulkan bahwa pengaruh paling dominan dalam meningkatkan kinerja pegawai di Polin ATMI adalah motivasi.

Penelitian ini memiliki keterbatasan karena hasil tidak dapat digeneralisir untuk semua pegawai di institusi pendidikan lainnya. Perlu juga penelitian ini diperluas dengan mengambil sampel dari institusi lain khususnya institusi pendidikan vokasi sehingga hasilnya memberikan perbandingan yang lengkap dan dapat menangkap kekhasan dari institusi vokasi lainnya. Dengan membandingkannya kita dapat memahami lebih objektif di dalam upaya peningkatkan kinerja pegawai di sebuah institusi pendidikan vokasi. Namun demikian, diharapkan penelitian ini tetap berguna sebagai referensi dalam memotret pengaruh work passion mengingat literatur tentang work passion dirasakan masih cukup terbatas.

\section{DAFTAR PUSTAKA}

Dharma, A. (2003). Manajemen Prestasi Kerja. CV Rajawali.

Handoko, T. (2002). Manajemen Personalia dan Sumber Daya Manusia. BPFE.

Hasibuan, M. (2013). Manajemen Sumber Daya Manusia. PT. Bumi Aksara.

Ho, V. T., Wong, S.-S., \& Lee, C. H. (2011). A Tale of Passion: Linking Job Passion and Cognitive Engagement to Employee Work Performance. Journal of Management Studies, 48(1), 26-47.

Holbeche, L. (2005). The High Performance Organization: Creating Dynamic Stability and Sustainable SuccessTitle. Roffey Park Management Institute.

Houlfort, R. \& Vallerand, N. (2003). Passion at Work: Toward a New Conceptualization. Information Age Publishing.

Jasiyah, R. (2018). The effect of ability and motivation on job satisfaction and employee performance. Archives of Business Research, 6(12), 12-23. https://doi.org/10.14738/abr.612.5644

Juliani, R., \& Purba, D. E. (2019). The mediating role of passion for work on the relationship between task significance and performance. Pertanika Journal of Social Sciences and Humanities, 27(3), 1945-1958.

Mangkunegara, A. P. (2003). Perencanaan dan Pengembangan Sumber Daya Manusia. Refika Aditama.

Martono, S., Khoiruddin, M., \& Wulansari, N. A. (2018). Remuneration Reward Management System As a. International Journal of Business \& Society, 19, 535545.

Munandar., A. S. (2001). Psikologi Industri dan Organisasi. UI Press.

Nelson, J. \& Quick, D. (2011). Principles of Organizational Behavior: Realities and Challenges. China Translation \& Printing Services Limited.

Prawirosentono, S. (2008). Manajemen Sumber Daya Manusia: Kebijakan Kinerja Karyawan. BPFE.

Qadeer, F., Ahmad, A., Hameed, I., \& Mahmood, S. (2016). Linking passion to 
organizational citizenship behavior and employee performance: The mediating role of work engagement. Pakistan Journal of Commerce and Social Sciences (PJCSS), 10(2), 316-334.

Rahayu, B., \& Ruhamak, M. D. (2017). Pengaruh Kepemimpinan, Insentif, Remunerasi Dan Motivasi Terhadap Kinerja Karyawan (Studi Kasus Pada Pt Industri Sandang Pangan Nusantara Cilacap). Ekonika : Jurnal Ekonomi Universitas Kadiri, 2(1), 1-

22. https://doi.org/10.30737/ekonika.v2i1.15

Robbins, S. (2006). Perilaku Organisasi. PT. Indeks Kelompok Gramedia.

Roe R. (2002). What makes a competent psychologist? European Psychologist, 7(3), 192-202. https://doi.org/10.1027//1016-9040.7.3.192

Samsudin, S. (2007). Manajemen Sumber Daya Manusia. Pustaka Aksara.

Santoso, U. (2012). Remunerasi Pegawai Negeri Sipil. http://uripsantoso.wordpres.com/2012/11/03/remunerasi-pegawai-negeri-sipil Stoeber, J., Childs, J. H., Hayward, J. A., \& Feast, A. R. (2011). Passion and motivation for studying: Predicting academic engagement and burnout in university students. Educational Psychology, 31(4), 513-528. https://doi.org/10.1080/01443410.2011.570251

Supranto, J. (2009). Statistika untuk Penelitian Pemasaran dan Sumber Daya Manusia. Mitra Wacana Media.

Supriadi, A. D., Suharto, S., \& Sodikin, S. (2018). The effect of competence and organization culture to employee performance with motivation as the mediation variable in the Directorate General of Fiscal balance-Ministry of Finance, Indonesia. Jurnal Perspektif Pembiayaan Dan Pembangunan Daerah, 5(4), 325336. https://doi.org/10.22437/ppd.v5i4.4606

Surya, M. (2004). Psikologi Pembelajaran dan Pengajaran. Pustaka Bani Quraisy.

Tanner, P. (2004). Assessing Business Excellence. Elsevier Butterworth-Heinemann.

Vallerand, R. J. (2008). On the psychology of passion: In search of what makes people's lives most worth living. Canadian Psychology, 49(1), 1-13. https://doi.org/10.1037/0708-5591.49.1.1

Vallerand, R. J., Mageau, G. A., Ratelle, C., Léonard, M., Blanchard, C., Koestner, R., Gagné, M., \& Marsolais, J. (2003). Les Passions de 1'Âme: On Obsessive and Harmonious Passion. Journal of Personality and Social Psychology, 85(4), 756-767. https://doi.org/10.1037/0022-3514.85.4.756

Vallerand, R. J., Salvy, S. J., Mageau, G. A., Elliot, A. J., Denis, P. L., Grouzet, F. M. E., \& Blanchard, C. (2007). On the role of passion in performance. Journal of Personality, 75(3), 505-534. https://doi.org/10.1111/j.1467-6494.2007.00447.x

Yahui, S., \& Jian, Z. (2015). Does work passion promote work performance? From the perspective of Dualistic Model of Passion. Advances in Management Accounting, 8(2), 9-15.

Zigarmi, D., Nimon, K., Houson, D., Witt, D., \& Diehl, J. (2009). Beyond engagement:Toward a framework and operational definition for employee work 
passion. Human Resource Development Review, 8(3), 300-326. https://doi.org/10.1177/1534484309338171 